\title{
ICT-Based Crosswords to Improve Elementary SchoolStudents' Critical Thinking Skills
}

\author{
Rohmah Suciningrum ${ }^{1}$, St. Y. Slamet ${ }^{2}$, and Hartono ${ }^{3}$ \\ \{rohmahsuciningrum@student.uns.ac.id ${ }^{1}$, slametsty@yahoo.co.id ${ }^{2}$, hartono@fkip.uns.ac.id ${ }^{3}$ \} \\ ${ }^{1,2,3}$ Elementary teacher education Program, Post graduate education Sebelas Maret \\ University, Indonesia
}

\begin{abstract}
Many students in Elementary Schools oftenfind difficulties and even give up to do the test. It means there are things to be improved in learning process in the class. Moreover, they are faced with the challenges of $21^{\text {st }}$ century learning that emphasize students' critical thinking skills and the use of ICT. Theskills require teacher's interventionby applying ICT-based CrosswordPuzzle media.This study aims to describe the importance of ICT-based Crossword Puzzle media to improve students' critical thinking skills. This research method was qualitative descriptive. The subjects were 48 students of the $4^{\text {th }}$ grade and 4 teachers from two Elementary Schools in Wonogiri Regency. The data were obtained from observations, questionnaires, interviews, and qualitative data analysis. The results show that the current learning has not been innovative. Crossword Puzzleis needed in accordance with the development of science and technology. It is also a fun game, stimulating students to solve problems. The accuracy in answering questions in it can strengthen the students' critical thinking skills. Therefore, the development of ICT-based Crossword Puzzle is needed to improve critical thinking skills in Elementary Schools to face the challenges of $21^{\text {st }}$ century education.
\end{abstract}

Keywords: Crossword Puzzle, ICT, critical thinking skills

\section{INTRODUCTION}

Students' critical thinking skills at this time can still be said to be low. Most students are lazy to think when facing difficult questions. They tend to answer difficult questions by predicting answers without knowing the correct answers. Their understanding of learning information has not been good enough so they find difficulties to answer the given questions. They are lazy to think critically in solving problems faced whereas critical thinking requires a deep understanding of the problems. The ability to remember information received is also a critical thinking ability that must be continuously trained [1].

Students' low critical thinking skills were reinforced by a research in China which states that most students in Asia have low thinking skills [2]. Memorizing culture is a choice of strategies in learning which causes students to be passive. Memorizing is far from 
understanding and easy to forget. Emphasis on critical thinking skills that students must possess will change the learning paradigm that was initially teacher-centered to be studentcentered. Critical thinking is a mental activity to solve a problem, and fulfill the desire for curiosity This opinion confirms that when someone formulates a problem, solves a problem, or wants to understand something, then he does a thinking activity. Students' critical thinking skills must be improved to deal with complexity problems in life in the $21^{\text {st }}$ century[3].

Critical thinking ability is very important because it is one of the high-level thinking skills. It is the main competency that students must have in order to be able to solve a problem and to live successfully. It is a universal skill in all fields, trying to solve any difficult problem. It is very important in the era of the development of science and technology. Provided with critical thinking skills, students can survive in society to meet current and future challenges. The quality of thinking of students by skillfully analyzing, evaluating, reconstructing what they think develops by practicing critical thinking[4]. The current learning is not innovative so it requires an innovative media to improve students' critical thinking skills.

Crossword Puzzle is a medium that is already familiar to everyone. Of the many games available, it is one fun game. It is also a language game by filling in the boxes with letters to form readable words, both vertically and horizontally. It can provide an understanding of material easily and deeply[5]. Students easily forget when receiving some materials. It is a reminder of the material that has been studied. Crossword Puzzle can be used as an innovative media that can improve students' critical thinking skills based on their strengths, that is, the use of Crossword Puzzle can increase students' concentration in facing the existing problems, without full concentration they will not succeed. Students do logical thinking when working on it. Troubleshooting problems that are difficult to do happily through the game of Crossword Puzzle[6].The use of media in $21^{\text {st }}$ century learning has entered the digital era. ICT (Information and Communication Technologies) is an important component that must be mastered by students and teachers as one of their competencies. The education undertaken must follow the existing technological developments. Teachers as agents of change must be able to create learning in accordance with the demands of the development of science and technology. Learning is done using ICT-based media that aims to improve critical thinking skills for children in Elementary School. Learning objectives will be realized by using a media. The use of learning media can generate motivation and stimulation for students in learning so that the desired learning objectives can be achieved optimally [7].

Nowadays, students are faced with $21^{\text {st }}$ century learning and a 4.0 industrial revolution that has a negative impact as well as a positive impact. The use of ICT in education is to take advantage of the positive effects that occur due to the rapid development of science and technology. With the use of ICT, it is expected to improve the quality of learning[8]. ICT is a computer-based technology including interconnected networks that can be used to search and store information in the form of data. ICT requires involvement between humans and humans, as well as human involvement with a machine.

ICT is used to create and support media that are relevant to the needs in the current field in order to achieve an educational goal[9]. ICT in education can help students to adapt to the community in order to be able to compete in achieving information and to possess skills as a means of facing life in the $21^{\text {st }}$ century. Most previous researches on Crossword Puzzle focused on understanding vocabulary. Stansfield's research emphasized the learning comprehension of science vocabulary[10], while Sims' research emphasized the mastery of biochemical vocabulary[11]. However, no one has researched for learning by combining ICT as an effort to improve critical thinking skills as in this research. 
The problem formulation of this study is, why ICT-based Crossword Puzzle is chosen as a medium to improve critical thinking skills? Based on the explanation above, it can be seen that this study is very important to describe the needs of learning media to face the $21^{\text {st }}$ century. This research can show that it is necessary to have fun and exciting learning media so that students can improve their critical thinking skills. The Crossword Puzzle Media created with ICT-based is the answer to the needs of the media in accordance with $21^{\text {st }}$ century learning. Critical thinking exercises will occur when students try to solve the answers to the questions in a Crossword Puzzle.

\section{METHOD}

The research used was qualitative with a descriptive approach. The subjects of this study were 48 students and 4 teachers of grade 4 in two Elementary Schools in Wonogiri District. This research method was also based on literature studies and field studies. Data from field studies were collected through observations, questionnaires, and interviews conducted on the $8^{\text {th }}$ to $13^{\text {th }}$ of January 2019 at $07.30-11.00$ WIB. The questionnaire analysis was processed through four stages. The first step is coding the data from the distribution of questionnaires. The second stage is tabulation of data to facilitate reading and grouping. The third stage is data analysis by describing and connecting data and information related to research. The fourth stage is making the interpretation of the results of the analysis in accordance with the problems [12]. The technique of checking the validity of the data in this study was triangulation techniques. Triangulation techniques were used to test the credibility of data by examining data to the same source with different techniques. The results of the triangulation comparison were then concluded to obtain valid data.

\section{RESULTS AND DISCUSSION}

This study uses data from the results of field studies and literature studies. Based on the field studies conducted, it can be obtained about the results of the research from observations, the distribution of questionnaires, and interviews conducted in two Elementary Schools consisting of 48 students and 4 teachers of the $4^{\text {th }}$ grade in Wonogiri Regency.

Observations are made to observe the activities carried out by teachers and students of the $4^{\text {th }}$ grade. Based on observations, it can be seen that teachers had not used innovative learning media. The media used were just blackboards and books. The teachers had limitations in the use of media based on new technology. The learning resources used were not up-to-date. Thes students' critical thinking was still low. This happened because the learning process was still passive, did not involve the students fully.

When learning activities took place, the students were less enthusiastic about following it. If the teacher gave a question, the students did not dare to answer. The teacher delivered the learning material with a talk, so students easily forgot about the material. It was proven that when the students were given some questions to analyze, they found difficulties. Learning activities had not revealed which students who were interactive, and still monotonous. Student activities in critical thinking did not yet appear. Based on previous research stated that critical thinking is always associated with intellectual abilities possessed by students and will appear in interactive and democratic learning [13].

The data of students' low critical thinking were obtained from the collection of observation instrument sheets from 48 students. The data were divided into three indicators of success. The first indicator is explaining, the second is understanding the material, and the 
third is analysing. Of the 48 students in explaining activites, 16 students $(33 \%)$ were finished, while 32 students $(67 \%)$ were not finished. In material understanding activities, students who had finished were $12(25 \%)$, while those that had not completed were 36 students $(75 \%)$. In the analysis activities, students who had finished were 8 students $(17 \%)$, and those who had not finished were 40 students $(83 \%)$.

The observation results are supported by the questionnaire distribution for the needs of ICT-based Crossword Puzzle media. Based on the results of questionnaires distribution by taking a sample of 48 students and 4 teachers in two elementary schools in Wonogiri Regency, an analysis of the importance of Cross Puzzle needs as a medium to improve critical thinking skills was obtained. The analysis is presented in table form as follows:

Table 1. The analysis of questionnaires distribution of ICT-based Crossword Puzzle media

\begin{tabular}{|c|c|}
\hline No & Question Analysis \\
\hline 1 & $\begin{array}{l}75 \% \text { of teachers had not used media that can improve students' critical } \\
\text { thinking skills }\end{array}$ \\
\hline 2 & $\begin{array}{l}75 \% \text { of teachers stated that student' score achievement above KKM } \\
\text { (Minimum Completion Criteria) was still small. }\end{array}$ \\
\hline 3 & $100 \%$ of teachers need media to deliver learning materials \\
\hline 4 & $50 \%$ of teachers had not used ICT media in learning. \\
\hline $\begin{array}{l}5 \\
6\end{array}$ & $\begin{array}{l}100 \% \text { of teachers agree if there is a development of Crossword Puzzle } \\
\text { media }\end{array}$ \\
\hline 7 & $\begin{array}{l}79 \% \text { of students answered that the teacher had not used interesting media } \\
73 \% \text { of students answered that they had difficulties in understanding the } \\
\text { material delivered by the teacher }\end{array}$ \\
\hline 9 & $\begin{array}{l}100 \% \text { of students answered that they were familiar with the game of } \\
\text { Crossword Puzzle }\end{array}$ \\
\hline 10 & $\begin{array}{l}90 \% \text { of students answered that the desired media is a learning game } \\
92 \% \text { of students answered that they agree if there is an ICT-based } \\
\text { crossword media development for learning. }\end{array}$ \\
\hline
\end{tabular}

The results of the questionnaire analysis show that $75 \%$ of teachers had not used media that could improve critical thinking skills and stated that students' scores above the Minimum Completion Criteria (KKM) were still small. $100 \%$ of teachers need media in learning, while those using ICT media are still 50\%. From 48 students, $79 \%$ of students answered that the teacher had not used interesting media. $73 \%$ of students had difficulty in understanding material. Over $90 \%$ of students were familiar with the crossword puzzle game. They strongly agree and support the development of ICT-based Crossword Puzzle media on thematic learning. The researcher can find out that the Crossword Puzzle is a media that is not boring and can improve students' critical thinking skills. The improvement in learning outcomes of more than $75 \%$ can occur if there are students who have a progress in critical thinking skills. This can be realized by the presence of innovative learning media. Innovative learning using media or models can improve students' critical thinking skills so they are able to adapt new knowledge [14].

The results of observations and questionnaire analyses are also supported by the results of interviews relating to the media for critical thinking skills. Based on the results of interviews with teachers and students of the $4^{\text {th }}$ grade from two Elementary Schools in Wonogiri district, information can be obtained that the teachers and students need learning media that can be 
used to improve critical thinking skills. They need appropriate media to deal with $21^{\text {st }}$ century education that is inseparable from the use of ICT. They agree and support that Crossword Puzzle is the right media for improving students' critical thinking skills.

Various problems occu.ring in the class show that students' critical thinking skills are still low. The problems happen because the teachers had not been maximal in using ICT-based learning media. Student learning activities can increase when teachers are able to use innovative learning media. Learning media that can be used is Crossword Puzzle. The benefit of the media is to attract students to learn while playing. Fun games can stimulate students to think critically. The game is adapted to current needs, namely digital games [15].Welldesigned digital games can facilitate learning because they are designed based on learning principles[16].

The research conducted by Shah et al. can provide support to the researcher regarding the use of Crossword Puzzle as an educational tool. The research conducted shows that more than $90 \%$ of students' learning about drug chemistry increased using Crossword Puzzle[17]. The differences between this research and that research are only on the subject and learning materials. The researcher took the subject in Elementary School with a thematic learning, while Shah took college students as the sample. The research conducted by Raymond et al. also stated that Crossword Puzzle has been successfully used to improve learning and the students think critically in solving accounting problems. The test was conducted on postgraduate students in the United States. As a result, they enjoyed its game and it was then recommended for the following semester [18].

The development of the Crossword Puzzle media is based on current conditions. The students live in a digital era that is inseparable from the role of ICT. Many research studies reveal extraordinary benefits regarding the use of ICT in education. Francis et al. in their research state that ICT can be used to improve student understanding and quality of education[19]. Previous researches have proven that ICT can help to (1) motivate student involvement in the classroom, (2) improve student learning activities, (3) improve problem solving, (4) communicate and make decision skilfully [20]. Based on the research, the researcher believe that the use of ICT in learning can improve students' critical thinking skills. It has challenges either from the teachers or the school. The research conducted by Kiru explained that the use of ICT in US K-12 schools did not change the teaching practices or student outcomes. This happened because the teachers had not received training or information about the effective use of ICT to improve the teaching and learning process[21]. Therefore, there was a research conducted by Semerci and Aydin regarding teacher attitudes towards the use of ICT in education based on gender, age, and teaching duration. The effective use of ICT in learning is influenced by some factors from both teachers and school environment conditions. From these factors, the teachers have a central role in the integration of ICT in the class [22].

ICT integration with Crossword Puzzle is needed to improve students' critical thinking skills. In the rapid development of science, students need to choose several skills in choosing useful information, evaluating the correctness of information, and making decisions. Critical thinking is an important skill in student decision making [23]. Critical thinking skills can be trained by working on it. Interactive and student-centered learning can be created with the use of this media.

Through the use of interesting and fun media, students are expected to be enthusiastic in learning. Students are encouraged to solve problems in Crossword Puzzle, so they can stimulate and train their critical thinking. This research is useful for the future because it can prepare children to think critically from an early age, which starts from the Elementary School 
level [24]. The problem in this study is that the time needed to work on it is sometimes too long, especially if you find a word that is not in accordance with the available box. Accuracy and perseverance are needed to solve the questions found in it. The problem can be overcome by the right time limitation in the use of the media. This research also has difficulty if it is not supported by teachers who are innovative and understand ICT. To overcome these problems, the right solution is to provide training for teachers.

\section{CONCLUSION}

Based on the results of the study, it can be concluded that the learning carried out must be in accordance with current development. At the time of the field study, it was found that the availability of learning media was still small, ICT utilization was not maximized and students' critical thinking skills were low. The learning needs to be developed innovatively, through interesting learning media. The teachers and students need Crossword Puzzle media to improve the students' critical thinking skills. This media is suitable to stimulate the students' enthusiasm in learning while playing so that critical thinking exercises can be carried out. Through this media, they can practice to solve a problem. Finally, the development of ICTbased Crossword Puzzle media is expected to be able to improve the students' critical thinking skills to the fullest.

\section{REFERENCES}

[1] M. Şahin and H. Dogantay, "Critical Thinking and Transformative Learning," J. Innov. Psychol. Educ. Didact., vol. 22, no. 1, pp. 103-114, 2018.

[2] L. Zhang and S. Kim, "Critical Thinking Cultivation in Chinese College English Classes," English Lang. Teach., vol. 11, no. 8, pp. 1-6, 2018.

[3] I. Tosuncuoglu, "Place of Critical Thinking in EFL," Int. J. High. Educ., vol. 7, no. 4, p. 26, 2018.

[4] F. Ariesta and E. Purwanti, "Build Critical Thinking Skills of Elementary School Students Through Comics social Science Based-Problem," Proc. Proc. 1st Work. Multimed. Educ. Learn. Assess. its Implement. Game Gamification, Medan Indones. 26th January 2019, Womela-GG, pp. 1-6, 2019.

[5] W. Orawiwatnakul, "Crossword Puzzles as a Learning Tool for Vocabulary Development," Electron. J. Res. Educ. Psychol., vol. 11, no. 2, pp. 413-428, 2013.

[6] M. Silberman, "Active Learning 101 Cara Belajar Siswa Aktif." Nuansa Cendekia, Bandung, p. 256, 2013.

[7] A. Arsyad, "Media Pembelajaran.” PT Grafindo Persada, Jakarta, p. 19, 2017.

[8] A. Meerza and G. Beauchamp, "Factors Influencing Undergraduates Attitudes Towards ICT: An Empirical Study in Kheis," Turkish Online J. Educ. Technol., vol. 16, no. 2, pp. 35-42, 2017.

[9] B. Ouedraogo, "Model of Information and Communication Technology (ICT) Acceptance and Use for Teaching Staff in Sub-Saharan Africa Public Higher Education Institutions," High. Educ. Stud., vol. 7, no. 2, p. 101, 2017.

[10] W. D. Stansfield, "Using Crossword Puzzles to Enhance Students' Learning of Technical Biological Terms," Am. Biol. Teach., vol. 76, no. 3, pp. 208-209, 2014.

[11] P. A. Sims, "Amino Acid Crossword Puzzle," J. Chem. Educ., vol. 88, no. 4, pp. 434436, 2011.

[12] A. Fadli, Suharno, and A. A. Musadad, "Deskripsi Analisis Kebutuhan Media Pembelajaran Berbasis Role Play Game Education untuk Pembelajaran Matematika," 
Pros. Semin. Pendidik. Nas. Pemanfaat. Smartphone untuk Literasi Produktif Menjadi Guru Hebat dengan Smartphone, no. 1, pp. 52-57, 2017.

[13] K. J. Lucas, "Chinese Graduate Student Understandings and Struggles with Critical Thinking: A Narrative-Case Study,” Int. J. Scholarsh. Teach. Learn., vol. 13, no. 1, pp. $1-7,2019$.

[14] D. Rizki Pebriana, "Effect of Problem Based Learning To Critical Thingking Skills," J. Elem. Educ., vol. 1, no. 1, pp. 109-118, 2017.

[15] Z. Hazar, "An Analysis of the Relationship between Digital Game Playing Motivation and Digital Game Addiction among Children," Asian J. Educ. Train., vol. 5, no. 1, pp. 31-38, 2019.

[16] M. L. Wu, "Educational Game Design as Gateway for Operationalizing Computational Thinking Skills among Middle School Students," Int. Educ. Stud., vol. 11, no. 4, p. 15, 2018.

[17] P. Samit Shah, PhD, Launa M. J. Lynch, PhD, and Lilia Z. Macias-Moriarity, "Crossword Puzzles as a Tool to Enhance Learning About Anti-Ulcer Agents.," Am. J. Pharm. Educ., vol. 74, no. 7, pp. 763-771, 2010.

[18] R. J. Elson, S. A. Ostapski, S. O’Callaghan, and J. P. Walker, "Enhancing The Understanding of Government and Nonprofit Accounting with The Puzzle Game: A Pilot Study," J. Instr. Pedagog., vol. 9, pp. 1-6, 2012.

[19] N. N. Francis, M. Ngugi, and J. Kinzi, "Influence of Selected Factors on the Implementation of Information and Communication Technology Policy in Public Secondary Schools in Naivasha Sub-County, Kenya," Int. J. Educ. Dev. Using Inf. Commun. Technol., vol. 13, no. 2, pp. 70-86, 2017.

[20] J. E. Hong, "Social Studies Teachers' Views of ICT Integration," Rev. Int. Geogr. Educ. Online, vol. 6, no. 1, pp. 32-48, 2016.

[21] E. W. Kiru, "Mathematics Teachers' Use of Information and Communication Technologies: An International Comparison," Int. J. Res. Educ. Sci., pp. 165-177, 2018.

[22] A. Semerci and M. K. Aydın, "Examining High School Teachers' Attitudes towards ICT Use in Education," Int. J. Progress. Educ., vol. 14, no. 2, pp. 93-105, 2018.

[23] D. Gurcay and H. O. Ferah, "High School Students' Critical Thinking Related to Their Metacognitive Self-Regulation and Physics Self-Efficacy Beliefs," J. Educ. Train. Stud., vol. 6, no. 4, p. 125, 2018.

[24] K. Saddhono and M. Rohmadi, "A Sociolinguistics Study on the Use of the Javanese Language in the Learning Process in Primary Schools in Surakarta, Central Java, Indonesia." Int. Edu. Stu., vol. 7 no.6 pp 25-30, 2014 